To cite this article: Arnau-Sabatés, L., Sala-Roca, J. i Jariot-Garcia, M.(2012). Emotional abilities as predictors of risky driving behaviour among a cohort of middle aged drivers. Accident Analysis \& Prevention, 45, 818-825. doi: 10.1016/j.aap.2011.07.021

Post-printed Version

\title{
Emotional abilities as predictors of risky driving behavior among a cohort of middle aged drivers.
}

\author{
Arnau-Sabatés, L., Sala-Roca, J. i Jariot-Garcia, M. \\ Universitat Autònoma de Barcelona
}

\begin{abstract}
The aim of this study is to analyze the relationship between emotional abilities and the influence of this relationship on self reported drivers' risky attitudes. The risky driving attitudes and emotional abilities of 177 future driving instructors were measured. The results demonstrate that risky attitudes correlate negatively with emotional abilities. Regression analysis showed that adaptability and interpersonal abilities explained the differences observed in the global risk attitude index. There were some differences in the specific risk factors. The variability observed in the speed and distraction and fatigue factors could also be explained by interpersonal and adaptability abilities. Nevertheless the tendency to take risks was explained by stress management and also interpersonal components. Emotional abilities have the weakest relation with alcohol and drugs factor, and in this case the variability observed was explained by the adaptability component. The results obtained highlight the importance take off including emotional abilities in prevention programs to reduce risky driving behaviours.
\end{abstract}

Key words: Driver behaviour, emotional abilities, risky driving, road safety.

\section{Introduction}

Traffic accidents constitute a global social and economic problem; millions of people die in traffic accidents every year (OCDE, 2006). Car crashes and traffic injuries are the ninth leading cause of death in the world (WHO, 2009). In Spain, 3,100 people were killed in road traffic accidents in 2007 (DGT, 2008). Spain's traffic control agency, Dirección General de Tráfico (DGT, 2008), estimates that $66 \%$ of drivers involved in fatal traffic accidents have committed traffic offenses; of all the accidents in 2007, 28\% involved speeding, 30.97\% involved alcohol and other drugs, and at least $37 \%$ involved driving while fatigued or distracted.

Recent research (Fernandes et al., 2007; Fernandes et al., 2010; Iversen, 2004) confirms that risky driving behavior has been a key contributor to road accidents (Elander et al., 2003). Risky behaviors associated with road accidents include speeding, drunk driving, driving while fatigued and not wearing seat belts (Fernandes et al., 2010). Examining certain variables associated with specific risky driving behaviors may explain individual differences in risk-taking behavior and traffic accident involvement, thereby enhancing knowledge that can improve traffic safety. 
Social cognition (attitudes and risk perception) research examining the determinants of risky driving behavior demonstrates that there is a strong association between specific risky attitudes and risky driving behavior (Fernandes et al., 2007; Iversen, 2004; Iversen and Rundmo 2004; Laujen and Summala, 1995; Tronsmoen, 2010; Ulleberg and Rundmo, 2002). In their research, Iversen (2004) and Tronsmoen (2010) observed that attitudes among young drivers were significantly associated with self-reported risk behavior. Young drivers who report safe traffic attitudes are likely to report less risky driving behavior. These results are consistent with Ulleberg and Rundmo's (2003) observation that attitudes toward risky behavior have a direct effect on risky behavior, although risk perception does not. However, these findings are inconsistent with other studies that suggest that risk perception affects risky behaviors (Harre and Sibley, 2007).

Considerable research has confirmed the influence of different personality traits (sensation seeking, normlessness and aggression) on risky driving behavior among young drivers (Ulleberg and Rundmo, 2003). Sensation seeking is linked to risky driving (Jonah et al., 2001; Ulleberg and Rundmo, 2003), and more specifically, it significantly predicts speeding (Jonah et al., 2001; Fernandes et al., 2010). Additionally, past research illustrates an association between sensation seeking and drunk driving (Fernandes et al., 2007). Other personality traits, such as anxiety, were significantly correlated with excitement-seeking and risky driving behavior (Oltendal and Rundmo, 2006). Moreover, aggressive behavior and driver rage (becoming frustrated and angry in traffic situations) were significantly related to speeding (Begg and Langley, 2004; Deffenbacher et al., 2003; Fernandes et al., 2010; Ulleberg and Rundmo, 2003) and were predictive of self-reported drunk driving (Begg et al., 2003). Based on this knowledge, emotional factors (e.g., anxiety, aggression) and lack of self-control are also related to risky driving (Ulleberg and Rundmo, 2003).

A review of previous research highlights the role of affective and emotional factors in perceiving and evaluating risk (Rundmo, 2002; Sjöberg, 2006; Slovic et al., 2004). Emotions and affective components highly influence human decision-making and perceived risk through an "heuristic affect" that greatly explains perceived risk (Slovic et al., 2004). Accordingly, Barrett and Salovey (2002) suggested that emotion plays a primary role in motivating behavior. Sjöberg (2006) recognized the influence of emotion in risk perception, but also claimed that emotions do not completely explain perceived risk. Thus, the role of emotional abilities and emotional intelligence should not be ignored in road safety.

Salovey and Mayer (1990) first defined emotional intelligence as the subset of social intelligence that involves the ability to monitor one's own and others' feelings and emotions, to discriminate between them and to use this information to guide one's thinking and actions. Subsequently, these authors redefined this concept as the ability to process emotional information, particularly in terms of the perception, assimilation, understanding and management of emotion (Mayer and Salovey, 1997). Ample research has confirmed that there is a relationship between emotional abilities and different aspects of human behavior (for a review see Mestre and Berrocal, 2007).

Most studies on risky driving behavior are related to risk perception, emotions, attitudes and some personality traits, but not emotional abilities. The present research is one of the first attempts to systematically explore the association between emotional ability 
and self-reported risky driving attitudes. We have not found any previous research that analyzes this relationship. It would be interesting to analyze this relationship because although personality is difficult to change, emotional abilities can be learned and developed throughout life. There are considerable practical implications of working with emotional abilities, including the ability to design intervention strategies aiming to enhance the effectiveness of changing drivers' attitudes.

The aim of this study is to analyze whether drivers' attitudes toward risk are related to their emotional abilities. We hypothesized that there is an association between emotional abilities and specific risky driving behaviors.

\section{Methods}

The sample consisted of 177 students, all of whom resided in Catalonia and had taken part in a driving instruction training course given by the Servei Català de Trànist (Catalan Traffic Service) from 2009-2010. The group was comprised of 51 women $(28.8 \%)$ and 126 men $(71.2 \%)$ between 23 and 55 years of age $(\mathrm{M}=34.3 ; \mathrm{SD}=7.2)$. Their driving experience ranged from 3 to 35 years $(\mathrm{M}=15.19 ; \mathrm{SD}=7.4)$.

A screening instrument was used to measure drivers' behavior, which was adapted from a validated questionnaire to evaluate risky driving attitudes (QAR-C, Qüestionari d'avaluació del risc del conductor) (Montané et al., 2006). This instrument contains 30 items on subjects' risky driving attitudes regarding various risk factors (Appendix 1). This instrument is comprised of a global risk attitude index $(\alpha=0.856)$ and four specific risk factor scales: speeding $(\alpha=0.813)$, alcohol and other drugs $(\alpha=0.680)$, distraction and fatigue $(\alpha=0.610)$ and risk-taking tendency $(\alpha=0.629)$. We also recorded participant's sex, age and driving experience.

To measure emotional abilities, we used the Emotional Quotient Inventory (EQI) (BarOn, 1997), a self-report measure of emotionally and socially intelligent behavior. The EQI contains 133 items with a Likert response scale and produces an estimate of emotional-social intelligence including a global emotional intelligence index and five composite scales comprised of 15 subscales (Table 1).

Table 1. Descriptions of all composite scales and subscales

\begin{tabular}{|c|c|}
\hline $\begin{array}{l}\text { Emotional composite } \\
\text { scales }\end{array}$ & Subscales \\
\hline \multirow{5}{*}{$\begin{array}{c}\text { INTRAPERSONAL } \\
\text { self-awareness and self- } \\
\text { expression }\end{array}$} & Self-regard - to accurately perceive, understand and accept oneself \\
\hline & Emotional self-awareness - to be aware of and understand one's emotions \\
\hline & $\begin{array}{l}\text { Assertiveness - to effectively and constructively express one's emotions and } \\
\text { oneself }\end{array}$ \\
\hline & Independence - to be self-reliant and free of emotional dependency on others \\
\hline & Self-actualization - to strive to achieve personal goals and actualize one's potential \\
\hline \multirow{3}{*}{$\begin{array}{c}\text { INTERPERSONAL } \\
\text { Social awareness and } \\
\text { interpersonal relationships }\end{array}$} & Empathy - to be aware of and understand how others feel \\
\hline & $\begin{array}{l}\text { Social responsibility - to identify with one's social group and cooperate with } \\
\text { others. }\end{array}$ \\
\hline & $\begin{array}{l}\text { Interpersonal relationships - to establish mutually satisfying relationships and } \\
\text { relate well with others }\end{array}$ \\
\hline \multirow{2}{*}{$\begin{array}{c}\text { STRESS } \\
\text { MANAGEMENT } \\
\text { emotional management } \\
\text { and regulation }\end{array}$} & Stress tolerance - to effectively and constructively manage emotions \\
\hline & Impulse control - to effectively and constructively control emotions \\
\hline
\end{tabular}




\begin{tabular}{cl}
\hline \multirow{2}{*}{$\begin{array}{c}\text { ADAPTABILITY } \\
\text { change management }\end{array}$} & $\begin{array}{l}\text { Reality testing - to objectively validate one's feelings and thinking with the } \\
\text { external reality }\end{array}$ \\
\cline { 2 - 2 } & $\begin{array}{l}\text { Flexibility - to adapt and adjust one's feelings and thinking to new situations } \\
\text { Problem solving - to effectively solve problems of a personal and interpersonal } \\
\text { nature }\end{array}$ \\
\hline $\begin{array}{c}\text { GENERAL MOOD } \\
\text { self motivation }\end{array}$ & \begin{tabular}{l} 
Optimism - to be positive and look on the brighter side of life \\
\cline { 2 - 2 }
\end{tabular} \\
\hline
\end{tabular}

Data were analyzed using the SPSS program (Statistical analysis Package for Social Sciences, $17^{\text {th }}$ version). In particular, we used descriptive analysis, correlations, t-test analysis and linear regression (stepwise).

\section{Results}

\subsection{Sex, age and driving experience}

T-test analysis uncovered differences in the sample based on sex: Men were older $[\mathrm{M}=35.6, \mathrm{SD}=7.5$ vs. $\mathrm{M}=31.2, \mathrm{SD}=5 ; \mathrm{t}(175)=3.8 ; \mathrm{p}<0.001]$ and had had their driver's license for longer than the female participants $[\mathrm{M}=16.9, \mathrm{SD}=7.5$ vs. $\mathrm{M}=10.9, \mathrm{SD}=4.9$; $\mathrm{t}(172)=5.1 ; \mathrm{p}<0.001]$. Women achieved higher scores for emotional self-awareness $[\mathrm{M}=107$ vs. $\mathrm{M}=100.2 ; \mathrm{p}<0.05 ; \mathrm{t}(175)=-2.3 ; \mathrm{p}<0.05]$, and men had higher scores for self-regard $[\mathrm{M}=112.2$ vs. $\mathrm{M}=107.5 ; \mathrm{p}<0.05 ; \mathrm{t}(175)=2.1 ; \mathrm{p}<0.05]$. Neither the global attitude toward risk nor the risk factors were correlated with subjects' age or driving experience. There was a weak correlation between age and the adaptability composite scale $(r=0.21 ; \mathrm{p}<0.05)$ and stress management $(\mathrm{r}=0.17 ; \mathrm{p}<0.05)$. Driving experience was not correlated with emotional intelligence.

\subsection{Risky behavior and emotional abilities}

The correlation analyses indicated several significant correlations between risky driving attitudes and emotional abilities and that the emotional intelligence quotient was significantly correlated with risky attitudes (Table 2):

Table 2. Correlations of components and scales of EQI and risky attitude, and their risk factors

\begin{tabular}{|c|c|c|c|c|c|}
\hline & $\begin{array}{c}\text { RISKY } \\
\text { ATTITUDE }\end{array}$ & $\begin{array}{l}\text { Speed } \\
\text { Factor }\end{array}$ & $\begin{array}{c}\text { Risk-taking } \\
\text { tendency } \\
\text { Factor }\end{array}$ & $\begin{array}{c}\text { Alcohol } \\
\text { and drugs } \\
\text { Factor }\end{array}$ & $\begin{array}{c}\text { Distraction } \\
\text { and } \\
\text { fatigue } \\
\text { factor }\end{array}$ \\
\hline EMOTIONAL INTELLIGENCE & $-.533^{\star * *}$ & $-.409 * * *$ & $-.458^{\star * *}$ & $-.247^{* *}$ & $-.454^{\star * *}$ \\
\hline $\begin{array}{l}\text { INTRAPERSONAL } \\
\text { Emotional self-awareness }\end{array}$ & $\begin{array}{l}-.456^{\star * *} \\
-.408^{\star * *}\end{array}$ & $\begin{array}{l}-.362^{\star * *} \\
-.335^{\star * *}\end{array}$ & $\begin{array}{l}-.392^{\star * \star} \\
-.301^{\star * *}\end{array}$ & $\begin{array}{l}-.186^{\star} \\
-.250^{\star *}\end{array}$ & $\begin{array}{l}-.385^{\star \star *} \\
-.322^{\star * *}\end{array}$ \\
\hline Assertiveness & $-.350^{\star * *}$ & $-.274^{\star \star \star}$ & $-.311^{\star \star *}$ & -.135 & $-.284^{\star \star *}$ \\
\hline $\begin{array}{l}\text { Self-regard } \\
\text { Self-actualization }\end{array}$ & $\begin{array}{l}-.356^{\star * *} \\
-.425^{\star * *}\end{array}$ & $\begin{array}{l}-.266^{* * *} \\
-.339^{* * *}\end{array}$ & $\begin{array}{l}-.381^{* * *} \\
-.333^{* * *}\end{array}$ & $\begin{array}{l}-.099 \\
-.156^{*}\end{array}$ & $\begin{array}{l}-.310^{\star * *} \\
-.396^{* * *}\end{array}$ \\
\hline Independence & $-.246^{\star *}$ & $-.202^{\star *}$ & $-.219^{\star *}$ & -.080 & $-.205^{\star *}$ \\
\hline INTERPERSONAL & $-.492^{* * *}$ & $-.396^{* * *}$ & $-390^{\star * *}$ & $-.266^{\star * *}$ & $-.414^{* * *}$ \\
\hline Empathy & $-.325^{\star \star \star}$ & $-.249^{* * *}$ & $-.266^{\star * *}$ & $-.172^{*}$ & $-.272^{\star \star *}$ \\
\hline Interpersonal relationships & $-.380^{* * *}$ & $-.291^{* * *}$ & $-.316^{\star * *}$ & $-.217^{* *}$ & $-.313^{* * *}$ \\
\hline Social responsability & $-.478^{\star * *}$ & $-.393^{* * *}$ & $-.365^{\star * *}$ & $-.256^{\star *}$ & $-.414^{* * *}$ \\
\hline ADAPTABILITY & $-.518^{\star * *}$ & $-.374^{* \star *}$ & $-.389^{* * *}$ & $-.287^{* *}$ & $-.466^{* * *}$ \\
\hline Problem solving & $-.405^{\star \star \star}$ & $-.311^{\star * *}$ & $-.375^{\star \star \star}$ & $-.151^{*}$ & $-.327^{* \star \star}$ \\
\hline $\begin{array}{l}\text { Reality testing } \\
\text { Flexibility }\end{array}$ & $\begin{array}{l}-.503^{* * *} \\
-.317^{* * *} \\
\end{array}$ & $\begin{array}{l}-.371^{* * *} \\
-.197^{* *}\end{array}$ & $\begin{array}{l}-.352^{\star * \star} \\
-.203^{\star *}\end{array}$ & $\begin{array}{l}-.286^{* * *} \\
-.247^{* *}\end{array}$ & $\begin{array}{l}-.480^{\star * *} \\
-.295^{\star * *}\end{array}$ \\
\hline
\end{tabular}




\begin{tabular}{|c|c|c|c|c|c|}
\hline STRESS MANAGEMENT & $-.433^{* \star *}$ & $-.331^{* * *}$ & $-.433^{* * *}$ & -.143 & $-.373^{\star * *}$ \\
\hline Stress tolerance & $-.374^{\star * *}$ & $-.267^{* * *}$ & $-.378^{* * *}$ & $-.161^{*}$ & $-.317^{* * *}$ \\
\hline Impulse control & $-.344^{* * *}$ & $-.281^{* * *}$ & $-.343^{\star * *}$ & -.078 & $-.303^{\star * *}$ \\
\hline AFECTIVITY & $-.390^{\star \star *}$ & $-.292^{\star * \star}$ & $-.393^{* * *}$ & $-.196^{\star *}$ & $-.300^{* * *}$ \\
\hline Happiness & $-.354^{* * *}$ & $-.274^{* * *}$ & $-.348^{* * *}$ & $-.194^{\star *}$ & $-.271^{* * *}$ \\
\hline Optimism & $-.347^{* * *}$ & $-.250^{\star *}$ & $-.358^{* * *}$ & $-.157^{*}$ & $-.268^{* * *}$ \\
\hline
\end{tabular}

$(* \mathrm{P}<0.05 ; * * \mathrm{P}<0.01 ; * * * \mathrm{P}<0.001)$.

The emotional intelligence quotient was negatively correlated with the global risk attitude index and the four risk factors. Nevertheless, the correlation of emotional intelligence with the alcohol and drugs factor was moderate. All of the emotional composite scales (intrapersonal, interpersonal, adaptability, stress management and affectivity) were highly correlated with the global attitude index.

All the emotional subscales of the EQI were correlated with the global attitude index. The emotional subscales also correlated negatively with the each of the four risk factors (speeding, risk-taking tendency, distraction and fatigue and alcohol and other drugs). The weakest of these correlations was between the emotional subscales and the alcohol and other drugs risk factor.

Stepwise regression analyses were conducted to determine which of the emotional composite scales and subscales best explained risky driving behavior. Results from the final model including only the variables that predicted risky driving behavior are presented in two parts. The first part describes the emotional composite scales and the emotional subscales that help explain the global risky attitude index. In the second part, we present the stepwise regression analysis for each risk factor (speeding, risk-taking tendency, alcohol and other drugs and distraction and fatigue).

The first stepwise regression showed that the adaptability and interpersonal emotional composite scales best explained differences found in the global attitude index $[\mathrm{F}(2,175)=38.3 ; \mathrm{p}<0.001]$. Taken together, these variables explained $30.5 \%$ of the variability in the global attitude index; adaptability explained the most variability (26.4\%) (Table 3).

Table 3. Stepwise Regression analysis: Contribution of emotional composite scales and subscales to explain global risky attitude index

\begin{tabular}{ccl}
\hline Corrected R square & Emotional components included & B \\
\hline 0.305 & Adaptability composite scale & $-0.345^{* * *}$ \\
& Interpersonal composite scale & $-0.273^{* *}$ \\
& & \multicolumn{2}{c}{ B } \\
\hline Corrected R square & Emotional subscales included & $-0.277^{* * *}$ \\
\hline 0.355 & Reality testing & $-0.496^{* * *}$ \\
& Social responsability & $-0.170^{*}$ \\
& Assertiveness & $0.248^{*}$
\end{tabular}

$(* \mathrm{P}<0.05 ; * * \mathrm{P}<0.01 ; * * * \mathrm{P}<0.001)$ 
As shown in Table 3, the second regression indicated that reality testing, social responsibility, assertiveness and empathy best explained the differences in the global risk attitude index $[\mathrm{F}(4,175)=23.6 ; \mathrm{p}<0.001]$. The model explained $34 \%$ of the variability in the global attitude index; reality testing explained the most variability $(24.8 \%)$.

When the specific risk factors were analyzed, differences were found in the relationships between emotional abilities and each of the various risky driving attitudes (Table 4).

Table 4. Stepwise Regression analysis: Contribution of emotional composite scales and subscales to explain risk attitude factors

Speed factor

\begin{tabular}{ccc}
\hline Corrected R square & Emotional components included & B \\
\hline 0.172 & Interpersonal & $-0.265^{* *}$ \\
& Adaptability & $-0.205^{*}$
\end{tabular}

Speed factor

\begin{tabular}{ccc}
\hline Corrected R square & Emotional subscales included & B \\
\hline 0.186 & Social responsability & $-0.277^{* *}$ \\
& Reality testing & $-0.233^{* *}$
\end{tabular}

Risk-taking tendency

\begin{tabular}{ccc}
\hline Corrected R square & Emotional components included & B \\
\hline 0.245 & Stress managment & $-0.338^{* * *}$ \\
Risk-tanking tendency & Interpersonal & $-0.232^{* *}$ \\
\hline Corrected R square & Emotional subscales included & B \\
\hline 0.266 & Problem solving & $-0.168^{*}$ \\
& Social responsability & $-0.202^{* *}$ \\
& Self-regard & $-0.189^{*}$ \\
& Impulse control & $-0.154^{*}$
\end{tabular}

Distraction and fatigue factor

\begin{tabular}{ccc}
\hline Corrected R square & Emotional components included & B \\
\hline 0.249 & Adaptability & $-0.365^{* * *}$ \\
& Interpersonal & $-0.190^{*}$
\end{tabular}

Distraction and fatigue factor

\begin{tabular}{ccc}
\hline Corrected R square & Emotional subscales included & B \\
\hline 0.275 & Reality testing & $-0.376^{* * *}$ \\
& Social responsability & $-0.234^{* *}$
\end{tabular}

Alcohol and drugs factor

\begin{tabular}{ccc}
\hline Corrected R square & Emotional components included & B \\
\hline 0.102 & Adaptability & $-0.327^{* * *}$ \\
Alcohol and drugs factor & & B \\
\hline Corrected R square & Emotional subscales included & $-0.2324^{* *}$ \\
\hline 0.104 & Reality testing & $-0.167^{*}$
\end{tabular}

$(* \mathrm{P}<0.05 ; * * \mathrm{P}<0.01 ; * * * \mathrm{P}<0.001)$. 
As shown in Table 4, the variability in the speeding factor was best explained by the interpersonal and adaptability EQI components $[F(2,175)=19.16 ; p<0.001]$. Taken together, these components explained $17.2 \%$ of the variability in the speeding factor; the interpersonal component explained the most variability $(15.2 \%)$. The regression model, including two of the emotional subscales, social responsibility and reality testing, $[\mathrm{F}(2,175)=21.01 ; \mathrm{p}<0.001]$, explained $18.6 \%$ of the variability observed in the speeding factor. Social responsibility accounted for the most variability in speeding $(15 \%)$.

The stress management and interpersonal components explained $24.5 \%$ of the variability in risk-taking tendency $[\mathrm{F}(2,175)=29.33 ; \mathrm{p}<0.001]$. Stress management explained $21.1 \%$ of the variability in risk-taking tendency. When we focused on the emotional subscales, four subscales were included in the regression model: problem solving, social responsibility, self-regard and impulse control $[F(3,175)=16.83$; $\mathrm{p}<0.001]$. The model explained $26.6 \%$ of the variability observed in the speeding factor; problem solving accounted for the most variance in this model $(17.4 \%)$.

The regression model explaining the differences found in the distraction and fatigue factor included the adaptability and interpersonal composite scales $[F(2,175)=30.01$; $\mathrm{p}<0.001]$. Taken together, the adaptability and interpersonal composite scales explained $24.9 \%$ of the variability in distraction and fatigue; the adaptability composite scale independently explained $23.2 \%$ of the variance. Reality testing and social responsibility explained $27.5 \%$ of the variability in the distraction and fatigue factor $[\mathrm{F}(2,175)=34.25$; $\mathrm{p}<0.001]$.

Emotional abilities had the weakest correlation with the alcohol and drugs factor: $10.2 \%$ of the observed variability in the global attitude to risk index was explained by adaptability components $[\mathrm{F}(1,175)=18.60 ; \mathrm{p}<0.001]$ and $10.4 \%$ was explained by the reality testing and flexibility subscales.

\section{Discussion and conclusions}

The results show that driving experience and age are not correlated with self-reported risky attitudes. Risky attitudes correlated negatively with emotional abilities. Adaptability and interpersonal abilities explained the variance observed in the global attitude index. These two components also explained the variability observed in the speeding, and distraction and fatigue risk factors. Nevertheless, risk-taking tendency was explained by stress management and interpersonal components. Emotional abilities had the weakest correlation with attitudes toward alcohol and drug related risks, and in this case, the variability observed was explained by the adaptability component.

Driving experience, in this sample, was not correlated with self-reported risky attitudes. These results are inconsistent with other research demonstrating that driving experience is associated with fewer safe attitudes (Lajunen and Summala, 1995; Tronsmoen, 2010), especially during the first three years after drivers get their license (Forsyth et al., 1995). Tronsmoen (2010) explained that experienced drivers evaluate and adapt traffic regulations for each driving context, and sometimes do not follow them rigorously; their driving attitudes become more flexible and "non ideal". However, these studies were conducted with young participants with limited driving experience. The present study's 
sample is older and has more driving experience. Future investigations must test the effect of driving experience and the evolution of the tendency to take risks over time in the general population. Age does not correlate with self-reported risky attitudes, but it does share a significant, albeit weak and positive, correlation with adaptability and stress management. These findings are consistent with Bar-On's (2000) findings, suggesting that emotional and social intelligence increase with age until the age of 50 . Therefore, age does not have a direct effect on risky behaviors, although it could have an indirect effect through the increase in emotional skills.

Risky attitudes correlate negatively with the emotional intelligence quotient and all emotional components. All the risk factors (speeding, risk-taking tendency, distraction and fatigue and alcohol and other drugs) were significantly associated with the emotional intelligence index and emotional composite scales used in the test. Even so, the correlation with alcohol and other drugs was small. Thus, the present study supports the assumption that emotional abilities influence specific risky driving behavior.

Regression analysis confirmed that interpersonal components (specifically, social responsibility ability) and the adaptability components (specifically, reality testing ability) explain a significant proportion of the variability in global risk attitude index compared to other composite scales.

As mentioned in the results, when the specific risky attitude factors were analyzed, differences between emotional components and each risky attitude were found. Interpersonal and adaptability components were found to be related to speeding. Risktaking tendency was explained mostly by the stress management composite scale. The emotional ability that explained the most variability in the alcohol and other drugs factor was adaptability (even in this study, the associations between the alcohol factor and emotional abilities were fairly weak, indicating that emotional abilities are not important predictors of drunk driving attitudes). Moreover, adaptability explained the most variance of the distraction factor. Therefore, the four factors in self-reported risky attitudes were partly explained through the interpersonal, adaptability and stress management components and, in this sample, they explained the most variance in risky driving behavior. These results are congruent with studies that analyze the relationship between risky driving attitudes and personality traits (e.g., Ulleberg and Rundmo, 2003) and social learning variables in Akers' applied social learning theory (e.g., Scott-Parker et al., 2009). There is currently much debate about whether the components of emotional intelligence are abilities or traits (Livingstone and Day, 2005). Nevertheless, it has been proven that emotional intelligence can be improved through education. In fact, many health education programs now include these emotional abilities because many correlations have been found between emotional intelligence and health behaviors. So, it is possible to include emotional abilities in preventive education programs.

It is interesting to note that some differences were also observed between emotional scales and each risk factor. In this respect, greater social responsibility and higher reality testing scores were associated with lower scores for the speeding factor. This is consistent with the observation that perceived consequences of a negative event are relevant enough to reduce speeding (Sjöberg, 1998). Furthermore, it also indicates the importance of the self-perception of responsibility in the relationship with other drivers 
on the road and the passengers in the driver's car. Therefore, drivers probably perceive the safe driving speed as a function of their perceived responsibility toward others.

Risk-taking tendency was explained mostly by the problem solving, social responsibility, self-regard and impulse control scales. Lower emotional self-control was associated with a higher tendency to take risks and break rules when driving. According to Ulleberg and Rundmo (2003), a lack of control over emotional components may increase risky driving and risk-taking. Nevertheless, perceived responsibility towards others again seems to be implicated. On the other hand, the negative relationship between self-regard and risk-taking tendency is interesting; this relationship may explain some suicides that occur when drivers crashed into other cars.

Reality testing ability explained the most variability observed in the alcohol and drugs and distraction and fatigue factors. Greater reality testing and a greater ability to adapt one's feelings to new situations were associated with a lower drunk driving tendency. Additionally, higher reality testing was also related to fewer intentions to drive while fatigued. These results are consistent with previous research indicating that perceived susceptibility (participants' vulnerability to having a crash or to being caught by the police) is relevant in explaining the variance in driving while fatigued (Fernandes et al., 2010). Hence, reality testing seems to be a relevant predictor of risk-taking behaviors while driving, especially when fatigued or otherwise distracted.

\subsection{Limitations and future research}

Several limitations arose in this study. It is not possible to generalize these results from future driving instructors to the general population, due to the number and type of participants. This preliminary research demonstrating the relationship between emotional abilities and risky driving behavior included a small sample of future driving instructors (middle aged and with an overrepresentation of men). Therefore, it would be good to corroborate these results in a more representative sample from the general population and consider different age groups and different driving experience. A larger sample would be necessary to detect stronger associations between risky driving behavior and emotional abilities.

The measures were self-report and thus, the influence of socially desirable response tendencies should not be excluded. Nevertheless, the participants were asked to respond sincerely and honestly on the anonymous questionnaires in order to minimize inaccurate responses (Zhao et al., 2006). Some risky driving studies confirmed the accuracy of self-reporting in this field (Iversen, 2004; Lajunen and Summala, 2003; Tronsmoen, 2010). Nevertheless, it would be interesting for future research to explore the indicators of drivers' risky behavior and match these with their index of traffic accidents to identify factors that may predict involvement in crashes.

\subsection{Practical implications}

The results demonstrate the importance of considering emotional abilities to understand individual risky driving behavior. Specifically, this research furthers our understanding of which emotional abilities are the most relevant in explaining and predicting the global risk attitude index and each of the specific attitudes such as speeding, drunk 
driving, driving while fatigued or distracted and risk-taking tendency, in order to improve attitudes toward safety.

This study highlights opportunities to design improved road safety intervention campaigns and programs (for pre-drivers and drivers) by developing the emotional abilities of drivers who engage in risky behaviors (separate for males and females) by influencing attitudes toward each risk factor. Ulleberg and Rundmo (2003) have already suggested the importance of promoting driving education and driving campaigns based on affective and emotional responses. Furthermore, a relevant intervention could also be carried out in future driving instructor training in Catalonia. This training could teach future instructors to influence the emotional abilities of pre-drivers and drivers, to improve their attitudes and encourage safe and responsible driving. 


\section{Appendix A.}

Fig. A1. Questionnaire items to measure drivers' attitudes toward risk.

1. I drive over the speed limit

\begin{tabular}{|l|l|l|l|}
\hline $\mathbf{1 .}$ & $\mathbf{2 .}$ & $\mathbf{3 .}$ & $\mathbf{4 .}$ \\
\hline Never & \multicolumn{2}{|c|}{ Always } \\
\hline
\end{tabular}

2. I drive 15 kilometers $\mathrm{p} / \mathrm{h}$ over the speed limit

\begin{tabular}{|l|l|l|l|}
\hline $\mathbf{1 .}$ & $\mathbf{2 .}$ & $\mathbf{3 .}$ & $\mathbf{4 .}$ \\
\hline Never & \multicolumn{3}{|c|}{ Always } \\
\hline
\end{tabular}

3. I race and have competitions with other people on the motorway and in the city

\begin{tabular}{|l|l|l|l|}
\hline $\mathbf{1 .}$ & $\mathbf{2 .}$ & $\mathbf{3 .}$ & $\mathbf{4 .}$ \\
\hline Never & \multicolumn{2}{|c|}{ Always }
\end{tabular}

4. I get irritated and upset easily if someone provokes me while I'm driving

\begin{tabular}{|l|l|l|l|}
\hline $\mathbf{1 .}$ & $\mathbf{2 .}$ & $\mathbf{3 .}$ & $\mathbf{4 .}$ \\
\hline Never & \multicolumn{2}{|c|}{ Always }
\end{tabular}

5. I drive after drinking a glass of liquor, two mixed drinks, two beers, or two glasses of wine.

\begin{tabular}{|l|l|l|l|}
\hline $\mathbf{1 .}$ & $\mathbf{2 .}$ & $\mathbf{3 .}$ & $\mathbf{4 .}$ \\
\hline Never & \multicolumn{3}{|c|}{ Always }
\end{tabular}

6. When I have drunk two glasses of alcohol, I look for a driver who has had nothing to drink

\begin{tabular}{l|l|l|ll|}
\hline 1. & 2. & 3. & 4. & \\
\hline Always & \multicolumn{3}{|r}{ Never }
\end{tabular}

7. I think I can drive well after taking drugs

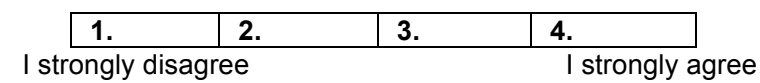

8. I think I can drive safely after drinking two glasses of liquor or three glasses of wine

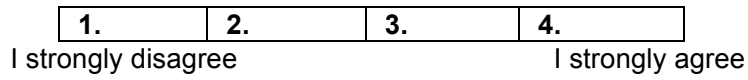

9. When I go out with other people, I make sure I don't drink so that I can take them home

\begin{tabular}{|l|l|l|ll|}
\hline 1. & 2. & 3. & 4. & \\
\hline Always & \multicolumn{3}{|r}{ Never } \\
\hline
\end{tabular}

10. The consumption of drugs and psychotropic substances does not increase the risk of having a traffic accident

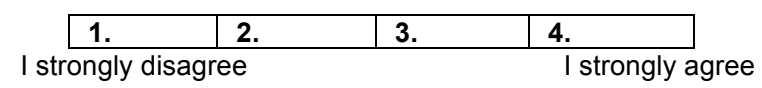

11. In the city at night, I drive as if I was on a motorway

\begin{tabular}{|l|l|l|l|}
\hline 1. & 2. & 3. & 4. \\
\hline
\end{tabular}


12. I normally drive over the speed limit in the city

\begin{tabular}{|l|l|l|l|}
\hline $\mathbf{1 .}$ & $\mathbf{2 .}$ & $\mathbf{3 .}$ & $\mathbf{4 .}$ \\
\hline Never & \multicolumn{3}{|c|}{ Always } \\
\hline
\end{tabular}

13. I take corners while driving over the speed limit

\begin{tabular}{|l|l|l|l|}
\hline $\mathbf{1 .}$ & $\mathbf{2 .}$ & $\mathbf{3 .}$ & $\mathbf{4 .}$ \\
\hline Never & \multicolumn{3}{|c|}{ Always }
\end{tabular}

14. Driving is an adventure

\begin{tabular}{|l|l|l|l|}
\hline $\mathbf{1 .}$ & $\mathbf{2 .}$ & $\mathbf{3 .}$ & $\mathbf{4 .}$ \\
\hline Never & \multicolumn{3}{|c|}{ Always } \\
\hline
\end{tabular}

15. I would install a radar-warning device in my vehicle

\begin{tabular}{|l|l|l|l|}
\hline $\mathbf{1 .}$ & $\mathbf{2 .}$ & $\mathbf{3 .}$ & $\mathbf{4 .}$ \\
\hline Never & \multicolumn{3}{|c|}{ Always } \\
\hline
\end{tabular}

16. I believe that GPS is an effective element that helps drivers reach their destination without any risks

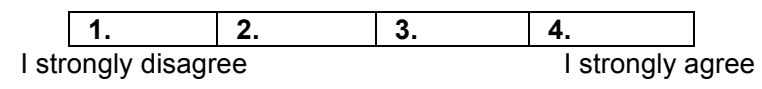

17. When I go on a long trip, I usually drive more than two consecutive hours in order to get to my destination faster

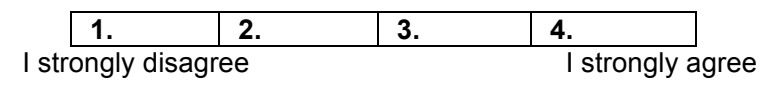

18. I concentrate while driving

\begin{tabular}{|l|l|l|ll|}
\hline $\mathbf{1 .}$ & $\mathbf{2 .}$ & $\mathbf{3 .}$ & $\mathbf{4 .}$ & \\
\hline
\end{tabular}

19. If I'm sleepy while driving, I park the vehicle in a safe place and go to sleep

\begin{tabular}{|l|l|l|ll|}
\hline $\mathbf{1 .}$ & $\mathbf{2 .}$ & $\mathbf{3 .}$ & $\mathbf{4 .}$ & \\
\hline Always & \multicolumn{3}{|r|}{ Never }
\end{tabular}

20. I turn the car radio volume up to the maximum

\begin{tabular}{|l|l|l|l|}
\hline $\mathbf{1 .}$ & $\mathbf{2 .}$ & $\mathbf{3 .}$ & $\mathbf{4 .}$ \\
\hline Never & \multicolumn{3}{|c|}{ Always } \\
\hline
\end{tabular}

21. I don't think the use of a hands-free mobile phone causes distractions to the driver

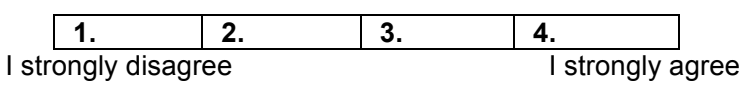

22. I use my mobile phone while driving

\begin{tabular}{|l|l|l|l|}
\hline 1. & $\mathbf{2 .}$ & $\mathbf{3 .}$ & $\mathbf{4 .}$ \\
\hline Never & \multicolumn{2}{|r}{ Always }
\end{tabular}

23. I slow down before going into an intersection even if there are no road signs or speed limits

\begin{tabular}{|l|l|l|ll|}
\hline 1. & 2. & 3. & 4. & \\
\hline Always & \multicolumn{3}{|r|}{ Never }
\end{tabular}


24. When it's foggy, I put the dimmed headlights on, slow down and do not overtake other vehicles

\begin{tabular}{|l|l|l|ll|}
\hline 1. & 2. & 3. & 4. & \\
\hline Always & \multicolumn{3}{|r}{ Never }
\end{tabular}

25. I drive fast whether it's raining or not

\begin{tabular}{|l|l|l|l|}
\hline 1. & $\mathbf{2 .}$ & $\mathbf{3 .}$ & $\mathbf{4 .}$ \\
\hline Never & \multicolumn{3}{|r}{ Always } \\
\hline
\end{tabular}

26. I respect speed limit signs when the road is under construction

\begin{tabular}{l|l|l|ll|}
\hline 1. & 2. & 3. & 4. & \\
\hline Always & \multicolumn{3}{|r}{ Never }
\end{tabular}

1. When the road seems safe, I drive over the speed limit

\begin{tabular}{|l|l|l|l|}
\hline $\mathbf{1 .}$ & $\mathbf{2 .}$ & $\mathbf{3 .}$ & $\mathbf{4 .}$ \\
\hline Never & \multicolumn{3}{|c|}{ Always } \\
\hline
\end{tabular}

2. When I'm in a hurry, I overtake other vehicles

\begin{tabular}{|l|l|l|l|}
\hline $\mathbf{1 .}$ & $\mathbf{2 .}$ & $\mathbf{3 .}$ & $\mathbf{4 .}$ \\
\hline Never & \multicolumn{3}{|c|}{ Always }
\end{tabular}

3. Before driving, I try to visualize the traffic jam that I will probably encounter and try to stay calm

\begin{tabular}{|l|l|l|ll|}
\hline 1. & 2. & 3. & 4. & \\
\hline Always & \multicolumn{3}{|r}{ Never }
\end{tabular}

4. Driving in a city makes me nervous and I try to get through it as quickly as possible

\begin{tabular}{|l|l|l|l|}
\hline 1. & 2. & 3. & 4. \\
\hline Never & \multicolumn{2}{|r|}{ Always } \\
\hline
\end{tabular}

\section{Acknowledgements}

The authors wish to thank Servei Català de Trànsit (Catalan Traffic Service) and Càtedra de Formació i Educació Viàries (Chair of Road Training and Education) for their support, and also thank the respondents who answered the questionnaires.

\section{References}

Barrett, L.F., Salovey, P., 2002. The wisdom in feeling. Guilford, New York.

Bar-On, R., 1997. The emotional quotient inventory (EQI): a test of emotional intelligence. Multi-Health Systems Inc., Toronto.

Bar-On, R., 2000. Emotional and social intelligence. Insights from the emotional quotient inventory. In: Bar-On, R., Parker, J.D.A. (Eds.), The handbook of emotional intelligence. Jossey-Bass, San Francisco, pp.363-388.

Begg,D.J., Langley, J.D., Stephenson, S., 2003. Identifying factors that predict persistent driving after drinking, unsafe driving after drinking, and driving after using cannabis among young adults. Accident Analysis and Prevention 35, 669-675. 
Begg, D.J., Langley, J.D., 2004. Identifying predictors of persistent non-alcohol or drug-related risky driving behaviours among a cohort of young adults. Accident Analysis and Prevention 36, 1067-1071.

Deffenbacher, J.L., Deffenbacher, D.M., Lynch, R.S., Richards, T.L., 2003. Anger, aggression, and risky behaviour: a comparison of high and low anger drivers. Behaviour Research and Therapy 41, 701-718.

DGT, 2008. Las principales cifras de la siniestralidad vial. DGT, Madrid.

Elander, J., West, R., French, D., 1993. Behavioural correlates of individual differences in road traffic crash risk: an examination of methods and findings. Psychological Bulletin 113 (2), 279-294.

Fernandes, R., Job, R.F.S., Hatfield, J., 2007. Different factors predict different risky driving behaviours: A challenge to the assumed generalizability of prediction and countermeasure. Journal of safety Research 38 (1), 59-70.

Fernandes, R., Hatfield, J., Job, R.F.S., 2010. A systematic investigation of the differential predictors for speeding, drink-driving, driving while fatigued, and not wearing a seat belt among young drivers. Transportation and Research Part F 13, 179196.

Forsyth, E., Mayock, G., Sexton, B., 1995. Cohort study of learner and novice drivers: Part 3, accidents, offences and driving experience in the first three years of driving, TRL Reports 111, 1-46.

Harré, N., Sibley, C.G., 2007. Explicit and implicit self-enhancement biases in drivers and their relationship to driving violations and crash-risk optimism. Accident Analysis and Prevention 39, 1155-1161

Iversen, H., 2004. Risk-taking attitudes and risky driving behaviour. Transportation and Research Part F 7, 135-150

Iversen, H., Rundmo, T., 2004. Attitudes towards traffic safety, driving behaviour and accident involvement among the Norwegian public. Ergonomics 47, 555-572.

Jonah, B.A., Thiessen, R., Au-Yeng, E., 2001. Sensation seeking, risky driving behaviour and behavioural adaptation. Accident Analysis and Prevention 33, 679-684

Lajunen, T., Summala, H., 1995. Driving experience, personality, and skill and safetymotive dimensions in drivers' self-assessments. Personality and Individual Differences 19 (3), 307-318.

Lajunen, T., Summala, H., 2003. Can we trust self reports of driving? Effects of impression management on driver behaviour questionnaire responses. Transportation and Research Part F 6, 97-107. 
Livingstone, H.A. and Day, A.L., 2005. Comparing the construct and criterion-related validity of ability-based and mixed-model measures of emotional intelligence. Educational and Psychological Measurement, 65(5), 757-779.

Mayer, J.D., Salovey, P., 1997. What is emotional intelligence?. In: Salovey, P., Sluyter, D. (Eds.), Emotional development and emotional intelligence: Implications for Educator. Basic Books, New York, pp.3-31.

Mestre, J.M., Fernández Berrocal, P., 2007. Manual de inteligencia emocional. Piramide: Madrid

Moen, B-E., 2007. Determinants of safety priorities in transport. The effect of personality, worry, optimism, attitudes and willingness to pay. Safety Science 45, 848863.

Montané, J., Jariot, M., Rodriguez Parrón, M., 2006. Qüestionari d'avaluació del risc d'accidents de trànsit dels conductors. Servei Català de Trànist, Barcelona

OECD, 2006. Young Drivers. The Road to Safety. OECD Publishing, Paris.

Rundmo, T., 2002. Associations between affect and risk perception. Journal of Risk Research 5, 119-135.

Scott-Parker, B., Watson, B., King, M.J., 2009. Understanding the psychosocial factors influencing the risky behaviour of young drivers. Transportation and Research Part $\mathrm{F}$ $12,470-482$.

Slovic, P., Finucane, M., Peters, E., McGregor, D.G., 2004. Risk as analysis and Risk as feelings: some thoughts about affect, reason, risk, and rationality. Risk analysis 24(2), $1-12$

Sjöberg, L., 1998. Worry and risk perception. Risk Analysis 18, 85-93.

Sjöberg, L., 2006. Will the Real Meaning of Affect Please Stand Up? Journal of Risk Research 9 (2), 101-108.

Tronsmoen, T., 2010. Associations between driver training, determinants of risky driving behaviour and carsh involvement. Safety Science 48, 35-45.

Salovey, P., Mayer, J.D., 1990. Emotional intelligence. Imagination, Cognition, and Personality 9, 185-211.

Ulleberg, P., Rundmo, T., 2002. Risk-taking attitudes among young drivers: The psychometric qualities and dimensionality of an instrument to measure young drivers risk-taking attitudes. Scandinavian Journal of Psychology 43(3), 227-237.

Ulleberg, P., Rundmo, T., 2003. Personality, attitudes and risk perception of risky driving behaviour among young drivers. Safety Science 41, 427-443. 
Zhao, J. Mann, R.E., Chipman, M., Adlaf, E., Stoduto, G., Smart, R.G., 2006. The impact of driver education on self -reported collisions among young drivers with a graduate licence. Accident Analyses and Prevention 38, 35-42.

Zuckerman, M., 1994. Behavioural expressions and Biosocial Bases of Sensation Deeking. Cambridge University Press, Cambridge.

WHO, 2009. Global Status Report on Road Safety. World Health Organisation, Geneva. 